\title{
KEBIJAKAN PEMERINTAH DAERAH DALAM PEMBERDAYAAN PEREMPUAN DI KABUPATEN DEMAK
}

\author{
Sri Kusriyah \\ Dosen Fakultas Hukum UNISSULA \\ Kusriyah@unissula.ac.id
}

\begin{abstract}
The general explanation of Law No. 23 of 2014 on Regional Government explains that the granting of the broadest autonomy to the regions is directed to accelerate the realization of the welfare of the community through the improvement of services, empowerment, and community participation. This research is related to community empowerment, especially local government policy in women empowerment. The method used in normative juridical research is by reviewing various laws related to women empowerment, especially the policy of local government of Demak regency, and to examine the programs conducted by the government Regions through the Office of Women's Empowerment. To analyze the research results used qualitative analysis by giving interpretation of local government policy related to empowering woman to answer problem in this research. The results showed that the policy of Demak Regency Government in the empowerment of women is: a) Empowerment of women entered in one of the Head of District Mission in 2011-2016, Bupati Regulation No. 07 of 2012 on General Guidelines Implementation of Gender Mainstreaming in Demak District, 401/0057/2016 on Gender Responsive Planning and Budgeting SKPD.b) Work programs implemented by KP2PA include: 1) improvement of women's quality of life and child protection, 2) institutional strengthening of gender mainstreaming, 3) harmony of policies to improve the quality of children and women,4) enhancement of participation and gender equality in development.
\end{abstract}

Keywords : Local Government Policy, Women Empowerment, Demak Regency.

\begin{abstract}
Abstrak
Penjelasan umum Undang-undang Nomor 23 tahun 2014 tentang Pemerintahan Daerah menjelaskan bahwa pemberian otonomi yang seluas-luasnya kepada daerah diarahkan untuk mempercepat terwujudnya kesejahteraan masyarakat melalui peningkatan pelayanan, pemberdayaan, dan peran serta masyarakat. Penelitian ini terkait dengan pemberdayaan masyarakat khususnya kebijakan pemerintah daerah dalam pemberdayaan perempuan. Metode yang digunakan dalam penelitian yuridis normatif, yakni dengan mengkaji berbagai peraturan perundangan yang terkait dengan pemberdayaan perempuan, khususnya kebijakan pemerintah daerah kabupaten Demak, serta mengkaji program-program yang dilakukan oleh pemerintah daerah melalui Kantor Pemberdayaan Perempuan. Untuk menganalisis hasil penelitian digunakan analisis kualitatif dengan cara memberikan penafsiran terhadap kebijakan pemerintah daerah terkait dengan pemberdayaan perempuan untuk menjawab permasalahan dalam penelitian ini. Hasil penelitian menunjukan bahwa kebijakan Pemerintah Kabupaten Demak dalam pemberdayaan perempuan adalah: a) Pemberdayaan perempuan masuk dalam salah satu Misi Kepala daerah tahun 2011-2016, Peraturan Bupati Nomor 07 Tahun 2012 tentang Pedoman Umum Pelaksanaan Pengrusutamaan Gender Di Kabupaten Demak, Surat Edraran Bupati Demak Nomor 401/0057/2016 tentang Perencanaan dan Penganggaran Responsif Gender SKPD.b) Program kerja yang dilaksanakan oleh KP2PA antara lain:1) peningkatan kualitas hidup perempuan dan perlindungan anak, 2) penguatan kelembagaan pengarusutamaan gender,3) keserasian kebijakan peningkatan kualitas anak dan perempuan,4) penigkatan peran serta dan kesetaraan gender dalam pembangunan.
\end{abstract}

Kata kunci : Kebijakan Pemerintah Daerah, Pemberdayaan Perempuan, Kabupaten Demak. 


\section{A. PENDAHULUAN}

Bagi masyarakat Indonesia yang mayoritas masyarakatnya pemeluk agama Islam, wakaf merupakan salah satu ibadah yang mempunyai dimensi sosial di dalam agama Islam. Praktik wakaf yang terjadi dalam kehidupan masyarakat belum sepenuhnya berjalan tertib dan efisien, sehingga dalam berbagai kasus harta benda wakaf tidak terpelihara sebagaimana mestinya, terlantar atau beralih ke tangan pihak ketiga dengan cara melawan hukum. Keadaan demikian itu, tidak hanya karena kelalaian atau ketidakmampuan nadzir dalam mengelola dan mengembangkan harta benda wakaf tetapi karena juga sikap masyarakat yang kurang peduli atau belum memahami status harta benda wakaf yang seharusnya dilindungi demi untuk kesejahteraan umum sesuai dengan tujuan, fungsi, dan peruntukan wakaf. ${ }^{1}$

Urusan pemberdayaan perempuan dan perlindungan anak saat ini berada di bawah Kementerian Pemberdayaan Perempuan dan Perlindungan Anak (Kementerian PP \& PA), yakni kementerian yang mempunyai tugas meyelenggarakan urusan di bidang pemberdayaan perempuan dan perlindungan anak dalam pemerintahan untuk membantu Presiden dalam menyelenggarakan pemerintahan negara dengan fungsinya Sebagai berikut:2

a) Perumusan dan penetapan kebijakan di bidang pemberdayaan perempuan dan perlindungan anak.

b) Koordinasi dan sinkronisasi pelaksanaan kebijakan di bidang pemberdayaan perempuan dan perlindungan anak.

c) Pengelolaan barang milik/kekayaan negara yang menjadi tanggung jawab Kementerian Pemberdayaan Perempuan dan Perlindungan Anak.

d) Pengawasan atas pelaksanaan tugas di lingkungan kementerian pemberdayaan perempuan dan perlindungan anak.

Salah satu urusan pemerintahan Kementerian Pemberdayaan Perempuan dan Perlindungan Anak terdapat dalam lampiran UU No 23 tahun 2014 tersebut terkait dengan pembagian urusan

Rachmadi Usman, 2009, Hukum Perwakafan D Indonesia, Sinar Grafika, Jakarta, hlm.121.

2 http://www.menegpp.go.id/, diakses tanggal 24 Pebruari 2016 pemerintahan antara pusat, provinsi dan kabupaten dalam urusan pemberdayaan perempuan dan perlindungan anak dalam sub urusan kualitas hidup perempuan, yang menjadi urusan pemerintah daerah: a) pelembagaan pengarusutamaan gender (PUG) pada lembaga pemerintah tingkat daerah kabupaten/kota, b) pemberdayaan perempuan bidang politik, hukum, sosoial dan ekonomi pada organisasi kemayarakatan tigkat kabupaten/kota, c) penguatan dan pengembangan lembaga penyedia layanan pemberdayaan perempuan tingkat kabupaten/kota.

Kabupaten Demak pada tahun 2010 dengan jumlah penduduk 1063 763, jumlah penduduk miskin 198800 , yakni $18,76 \%$, dengan pemeluk agama Islam sebesar $99,45 \% .^{3}$ Kabupaten Demak memiliki Visi “Terwujudnya Masyarakat yang Semakin Sejahtera, Maju, Mandiri Dan Kompetitif Dalam Suasana Kehidupan yang Kondusif, Agamis dan Demokratis. Dengan demikian kebijakan yang dilakukan oleh kabupaten Demak harus ditujukan untuk mewujudkan visi yang telah ditetapkan, visi tersesebut kemudian dirumuskan lebih lanjut dalam kebijakan umum rencana pembangunan jangaka menengah daerah (RPJMD) Kabupaten Demak tahun 2011-2016 antara lain yakni: ${ }^{4}$

Kebijakan umum yang terkait dengan ketahanan pangan dan ekonomi kerakyatan,

a) Kebijakan umum yang terkait dengan pemberdayaan perempuan, perlindungan anak, dan pengendalian pertumbuhan penduduk,

b) Kebijakan umum yang terkait dengan kualitas infrastruktur ekonomi dan sosial,

c) Kebijakan umum yang terkait dengan pembangunan pedesaan dan pengembangan kawasan-kawasan strategis.

Berdasarkan pertimbangan tersebut diatas maka penelitian ini akan diajukan permasalahpermasalahan yang dirumuskan sebagai berikut:

1. Bagaimanakah kebijakan pemerintahan daerah kabupaten Demak dalam pemberdayaan perempuan sebagai salah satu sarana pengentasan kemiskinan?

\footnotetext{
Demak dalam angka, Badan Pusat Statistik Kabupaten Demak, 2011.

4 Sumber BAPPEDA Kabupaten Demak, 2014.
} 
2. Program-program apa saja yang dilakukan oleh pemerintah daerah kabupaten Demak dalam pemberdayaan perempuan.

\section{B. Metode Penelitian}

Peneltian ini dilakukan dengan menggunakan metode pendektan yuridis normatif, yakni dengan mengkaji peraturan hukum yang terkait dengan pemberdayaan perempuan terutama berupa kebijakan pemerintah daerah dalam pemberdayaan perempuan di Kabupaten Demak. Data yang diperlukan dalam penelitian ini adalah data sekunder berupa kebijakan pemerintah daerah kabupaten Demak yang mengatur tentang pemberdayaan perempuan. Hasil penelitian dianalisis secara kualitatif dengan cara memberikan penafsiran terhadap data yang sudah terkumpul untuk menjawab permasalahan yang duajukan dalam penelitian ini.

\section{Pembahasan}

1. kebijakan pemerintahan daerah kabupaten Demak dalam pemberdayaan perempuan sebagai salah satu sarana pengentasan kemiskinan

Kehadiran UU Yayasan atau Badan Hukum Nir Laba sudah barang tentu akan memberi kepastian hukum yang selama ini tidak ada. Bahkan UU Yayasan atau Badan Hukum Nir Laba dapat menjadi dasar untuk menindak apabila terjadi penyimpangan. Hanya saja apabila Undang-undang Yayasan hanya berisi tentang prosedur pendirian belaka atau prosedur-prosedur lainnya, walaupun baik tetapi tidak optimal. Undang-undangYayasan atau Badan Hukum Nir Laba harus berisi pula ketentuan yang dapat memaksa pengurus beserta organ lainnya untuk mengelola yayasan secara profesional dan baik.

Visi kabupaten Demak tahun 20112016 adalah "Terwujudnya Masyarakat Yang Semakin Sejahtera, Mandiri dan Kompetitif Dalam Suasana Kehidupan Yang Kondusif, Agamis Dan Demokratis". Untuk melaksanakan visi tersebut maka misi kepala daerah adalah: ${ }^{5}$

\footnotetext{
5 Rencana Strategis Kantor Pemberdayaan Perempuan dan Perlindungan Anak (KP2PA) Kabupaten Demak, 2011-2016, KP2PA, 2012, hlm. 28.
}

a. Mewujudkan birokrasi yang bersih, efektif, efisien dan akuntabel,

b. Meningkatkan kualitas pendidikan dan pelayanan kesehatan,

c. Meningkatkan ketahanan pangan dan ekonomi rakyat yang berbasis pertanian, kelautan dan perikanan, UMKM dan pariwisata,

d. Mendorong investasi dan menciptakan lapangan kerja,

e. Meningkatkan kerukunan dan kualitas beragama,

f. Meningkatkan pemberdayaan perempuan, perlindungan anak dan pengendalian jumlah penduduk.

g. Mengembangkan potensi pemuda, olah raga dan seni budaya,

h. Mengembangkan dan meningkatkan kualitas infrastruktur ekonomi dan sosial,

i. Mempercepatpembangunan pedesaan dan kawasan-kawasan strategis

j. Meningkatkan kualitas kehidupan demokratis.

Misi yang terkait dengan KP2PA adalah misi keenam yaitu meningkatkan pemberdayaan perempuan perlindungan anak dan pengendalian jumlah penduduk, dengan pokok program sebagai berikut:

a. Meningkatkan pemasyarakatan pengarusutamaan gender.

b. Mengembangkan kerjasama dengan organisasi perempuan.

c. Membantu organisasi-organisasi perempuan.

Pelaksanakan program tersebut pemerintah daerah kabupaten Demak, mengeluarkan Peraturan Bupati Demak Nomor 7 Tahun 2012 tentang Pedoman Umum Pelaksanaan Pengarusutamaan Gender Di Kabupaten Demak. Ketentuan umum Pasal 1 ayat (10) menjelaskan bahwa yang dimaksud dengan pengarusutamaan gender yang selanjutnya disingkat PUG adalah strategi yang dibangun untuk mengintegrasikan gender menjadi satu dimensi integral dari perencanaan, penyusunan, pelaksanaan, pemantauan, dan evaluasi atas kebijakan, program dan 
kegiatan pembangunan di daerah. (11) maksud pengarusutamaan gender adalah konsep yang mengacu pada perbedaan peran dan tanggung jawab laki-laki dan perempuan yang terjadi akibat dari dan dapat berubah oleh keadaan sosial, dan budaya masyarakat. Ayat (12) kesetaraan gender adalah kesamaan kondisi bagi laki-laki dan perempuan untuk memperoleh kesempatan dan hak-haknya sebagai manusia, agar mampu berpartisipasi dalam kegiatan politik, ekonomi, sosial budaya, pertahanan dan keamanan, dan kesamaan dalam menikmati hasil-hasil pembangunan.

Maksud dibentuknya pedoman umum pelaksanaan pengarusutamaan gender di daerah diatur dalamPasal 2, yakni dimaksudkan untuk memberikan pedoman kepada pemerintah daerah dalam penyelenggaraan pemerintahan, pembangunan, dan pelayanan masyarakat yang berperspektif gender. Pasal 3 menjelaskan tujuan pedoman terebut antara lain:

a. Memberikan acuan bagi aparatur pemerintah daerah dalam menyusun strategi mengintegrasikan gender yang dilakukan melalui perencanaan, pemantauan, dan evaluasi atas kebijakan, program, dan kegiatan pembangunan.

b. Mewujudkan perencanaan berperspektif gender melalui pengintegrasian pengalaman, aspirasi, kebutuhan, potensi, dan penyelesaian permasalahan laki-laki dan perempuan.

c. Mewujudkan kesetaraan dan keadilan gender dalam kehidupan berkeluarga, berbangsa, dan bernegara.

d. Mewujudkan pengelolaan anggaran daerah yang responsif gender.

e. Meningkatkan kesetaraan dan keadilan dalam kedudukan peran, dan tanggungjawab laki-laki dan perempuan sebagai insan dan sumber daya pembangunan.

f. Meningkatkan peran dan kemandirian lembaga yang menangani pemberdayaan perempuan.
Wujud dari pelaksanaan Peraturan Bupati Nomor 07 tahun 2012, saah satunya adalah dikeluarkannya Surat Edaran Bupati Demak Nomor 401/0142/2016, tanggal 25 April 2015 perihal Perencanaan dan Penganggaran Responsif Gender yang ditujukan kepada seluruh SKPD kabupaten Demak, yang antara lain berisi:

a. Kebijakan,SeluruhSKPDberkewajiban untuk menyusun perencanaan dan penganggaran responsif gender (PPRG) pada tahun anggaran 2016.

b. Pelaksanaan, Sehubungan dengan hal tersebut SKPD agar menyusun dokumen anggaran responsif gender (ARG) dengan langkah-langkah sebagai berikut:

1. Menyiapkan program dan kegiatan yang akan disusun dengan strategi pengarusutamaan gender.

2. Menyiapkan data pilah gender, baik kuantitatif maupun kualitatif yang menggambarkan indikator, akses, partisipasi, kontrol dan manfaat antara perempuan dan laki-laki dalam keseluruhan program/ kegiatan yang dilaksanakan.

3. Melakukan analisis gender terhadap program/kegiatan yang akan dilaksanakan, merumuskan indikator kinerja output dan outcome yang terukur dengan menggunakan metode gender analisis pathway (GAP), sebagaimana form terlampir. Menyusun gender budget statement atau pernyataan anggaran gender (terlampir) yang menjadi bagian tidak terpisahkan dari RKASKPD responsif gender tahun anggaran 2016.

c. Program dan kegiatan yang di ARG kan tersebut diserahkan kepala Kepala Bappeda kabupaten Demak dengan tembusan Kepala kantor Pemberdayaan Perempuan dan Perlindungan Anak kabupaten Demak. 


\section{Program-program Pemerintah \\ Kabupaten Demak Dalam \\ Pemberdayaan Perempuan}

Pemerintah daerah kabupaten Demak melalui Kantor P2PA telah berupaya untuk memberdayakan perempuan yang dituangkan dalam rencana strategis (Renstra) tahun 2011-2016. Dalam Renstra tersebut antara lain mengatur: 6

1. Tugas Pokok KP2PA

Melaksanakan urusan pemerintah daerah di bidang pemberdayaan perempuan dan perlindungan anak.

2. Fungsi KP2PA

a. Perumusan kebijakan teknis di bidang pemberdayaan perempuan dan perlindungan anak.

b. Pengkoordinasian dan pelaksanaan program, monitoring, evaluasi dan pelaporan di bidang pemberdayaan perempuan dan perlindungan anak.

c. Pengendalian pelaksanaan program bidang pemberdayaan perempuan dan perlindungan anak,

d. Pengelolaan tata kantor.

Untuk melaksanakan tugas pokok dan fungsi KP2PA mempunyai tugas sebagai berikut:

a. Merumuskan program dan kegiatan kantor berdasarkan peraturan perundang-undangan yang berlaku dan sumber data yang tersedia sebagai pedoman pelaksanaan kegiatan.

b. Mengarahkan tugas bawahan sesuai bidang-bidang tugasnya guna kelancaran pelaksanaan tugas.

c. Melaksanakan koordinasi dengan instansi terkait untuk mendapatkan masukan informasi serta untuk mengevaluasi permasalahan agar diperoleh hasil kerja yang optimal.

6 Rencana Strategis Kantor Pemberdayaan Perempuan dan Perlindungan Anak Kabupaten Demak, Tahun 2011-2016., hlm 6 d. Merumuskan kebijakan Bupati di bidang pemberdayaan perempuan dan perlindungan anak berdasarkan wewenang yang diberikan dan peraturan perundang-undangan yang berlaku sebagai bahan arahan operasional kantor.

e. Melaksanakan koordinasi dan fasilitasi program dan kegiatan di bidang pengarusutamaan gender, kualitas hidup dan perlindungan perempuan serta anak.

f. Mengendalikan pelaksanaan program dan kegiatan pengarusutamaan gender, kualitas hidup dan perlindungan perempuan serta perlindungan anak.

g. Membina pelaksanaan urusan pemerintahan bidang pemberdayaan perempuan dan perlindungan anak sesuai dengan peraturan perundang-undangan yang berlaku dan kebijakan yang ditetapkan Bupati.

h. Mengevaluasi pelaksanaan program dan kegiatan operasional pengarusutamaan gender, kualitas hidup dan perlindungan perempuan serta anak.

i. Melaksanakan monitoring. Evaluasi dan menilai kinerja bawahan secara berkala melalui sistem penilaian yang tersedia sebagai cerminan penampilan kinerja.

j. Menyampaikan laporan pelaksanaan tugas kepada atasan sebagai bahan masukan guna kelancaran pelaksanaan tugas.

k. Menyampaikan saran dan pertimbangan kepada atasan sebagai bahan masukan guna kelancaran tugas,

I. Melaksanakan tugas kedinasan lain sesuai perintah atasan.

\section{Visi KP2PA}

Visi merupakan suatu kondisi yang diinginkan oleh seluruh komponen SKPD. Cita-cita ini menjadi arah dalam menyusun 
strategi dan keinginan dalam setiap tahun kegiatan. Adapaun Visi KP2PA kabupaten Demak adalah "Terwujudnya kesetaraan gender dan keadilan gender, kesejahteraan dan perlindungan anak dalam kehidupan keluarga, masyarakat, bangsa dan negara".

4. Misi KP2PA

Untuk mencapai visi di atas misi yang harus dilakukan adalah:

a. Meningkatkan pengarusutamaan gender melalui fasilitas kelembagaan, kesetaraan dan keadilan gender dalam berbagai bidang pembangunan.

b. Meningkatkan kualitas hidup perempuan

c. Mengurangi segala bentuk kekerasan berbasis gender terhadap perempuan.

d. Meningkatkan perlindungan anak.

Terkait dengan pemberdayaan perempuan dan pengentasan kemiskinan terdapat pada misi yang pertama dan kedua $(a, b)$, kondisi yang diinginkan kedepan adalah:

a. Pemberdayaan perempuan, meliputi:

1. Terdapat kebijakan, program dan kegiatan penanggulangan kemiskinan responsif gender yang sinergi antara SKPD terkait dan kelembagaan masyarakat.

2. Peningkatan kualitas hidup perempuan untuk mendukung komitmen global MDG's, seperti pengingkatan rata-rata lama anak sekolah perempuan, penurunan kematian ibu dan bayi, peningkatan partisipasi politik perempuan, peningkatan akses perempuan pada lapangan pekerjaan, peningkatan kesetaraan gender di semua bidang pembangunan.

3. Adanya peningkatan ekonomi perempuan melalui mod- el-model pelatihan dan pendampingan yang terintegrasi dengan revitalisasi gerakan kasih sayang ibu dan bayi (GSIB) dan perlindungan perempuan.

4. Penurunan kasus kematian ibu dan bayi melalui GSIB.

5. Adanya peningkatan kualitas pelayanan terpadu korban kekerasan berbasis gender dan korban tindak pidana perdagangan orang melalui optimalisasi pusat pelayanan terpadu (PPT) kabupaten Demak.

6. Adanya percepatan pemberantasan buta aksara perempuan.

7. Adanya peningkatan partisipasi perempuan dalam lembaga-lembaga pengambil keputusan dan dalam proses pengambilan keputusan.

8. Tersedianya sistem perlindungan dan peningkatan kualitas hidup perempuan.

9. Peningkatan pemahaman dan kemampuan pengarusutamaan gender bagi pengelola program di suruh SKPD kabupaten serta stakeholder lainnya.

10. PUG dengan fokus utama perencanaan penganggaran responsif gender (PPRG) pada semua bidang pembangunan.

Berdasarkan tujuan yang diinginkan KP2PA membentuk program yang terkait dengan peningkatan kualitas hidup perempuan, program ini ditujukan untuk meningkatkan kualitas peran, dan kedudukan perempuan dalam berbagai bidang kehidupan dan pembangunan, kegiatan pokok yang dilaksankan antara lain: ${ }^{7}$ 
1. Peningkatan upaya perlindungan perempuan dari tindak kekerasan, eksploitasi, dan diskriminasi termasuk usaha pencegahan dan penanggulangannya.

2. Pelaksanaan komunikasi, informasi, dan edukasi peningkatan kualitas hidup dan perlindungan perempuan serta kesetaraan dan keadilan gender.

3. Peningkatan peran kelembagaan dan jaringan kelem- bagaan pemberdayaan perempuan.

4. Peningkatan upaya perlindungan perempuan termasuk lansia dan cacat.

Kebijakan KP2PA terkait dengan misi dijabarkan sebagai berikut:

1. Misi I

Meningkatkan PUG melalui fasilitas kelembagaan, kesetaraan dan keadilan gender dalam berbagai bidang.

\begin{tabular}{|c|c|c|c|}
\hline Tujuan & sasaran & strategi & Kebijakan \\
\hline $\begin{array}{l}\text { Meningkatnya peran } \\
\text { perempuan dalam } \\
\text { kegiatan politik dan } \\
\text { pelayanan publik. }\end{array}$ & $\begin{array}{l}\text {-Meningkatnya } \\
\text { keterwakilan } \\
\text { perempuan di } \\
\text { lembaga legislatif. } \\
\text {-Meningkatnya } \\
\text { keterwakilan } \\
\text { perempuan di } \\
\text { lembaga eksekutif. }\end{array}$ & $\begin{array}{l}\text { Pengembangan } \\
\text { pendidikan politik bagi } \\
\text { perempuan. } \\
\text {-Peningkatan } \\
\text { kompetensi bagi } \\
\text { perempuan dalam } \\
\text { pengenbangan karir. }\end{array}$ & $\begin{array}{l}\text {-Pelatihan dan kaderisasi } \\
\text { bagi perempuan dalam partai } \\
\text { politik. } \\
\text {-Pendidikan dan pelatihan } \\
\text { bagi perempuan dalam } \\
\text { rangka peningkatan } \\
\text { kompetensi. }\end{array}$ \\
\hline
\end{tabular}

2. Misi II Meningkatkan kualitas hidup perempuan

\begin{tabular}{|c|c|c|c|}
\hline Tujuan & Sasaran & Strategi & Kebijakan \\
\hline $\begin{array}{l}\text { Terwujudnya kualitas } \\
\text { hidup perempuan yang } \\
\text { mandiri dan bertaqwa } \\
\text { kepada Tuhan YME. }\end{array}$ & $\begin{array}{l}\text {-Meningkatnya } \\
\text { perempuan dalam } \\
\text { dunia kerja. } \\
\text {-Meningkatnya kualitas } \\
\text { pendidikan perempuan } \\
\text {-Meningkatnya } \\
\text { kemampuan } \\
\text { berwirausaha bagi } \\
\text { perempuan. }\end{array}$ & $\begin{array}{l}\text {-Pengembangan } \\
\text { pelatihan kerja bagi } \\
\text { perempuan. } \\
\text {-penyuluhan } \\
\text { pentingnya pendidikan } \\
\text { bagi perempuan. } \\
\text {-Pengembangan } \\
\text { diklat wirausaha bagi } \\
\text { perempuan. }\end{array}$ & $\begin{array}{l}\text {-pemberian } \\
\text { kesempatan kerja bagi } \\
\text { perempuan } \\
\text {-pembinaan } \\
\text { pentingnya pendidikan } \\
\text { bagi permpuan } \\
\text {-peningkatan pelatihan } \\
\text { kewirausahaan bagi } \\
\text { perempuan. }\end{array}$ \\
\hline
\end{tabular}

Langkah berikutnya sebagai pelalsanaan Visi dan Misi tersebut KP2PA membuat rencana program kerja tahun 2011-2016 antara lain sebagai berikut:

1. Program Peningkatan Kualitas Hidup dan Perlindungan Perempuan

Program ini ditujukan untuk meningkatkan kualitas, peran dan kedudukan perempuan di berbagai bidang kehidupan dan pembangunan, kegiatan pokok yang dilaksanakan antara lain: a. Peningkatan upaya perlindungan perempuandaritindakkekerasan, eksploitasi, dan diskriminasi termasuk usaha pencegahan dan perlindungannya,

b. Pelaksanaan komunikasi, informasi dan edukasi peningkatan kualitas hidup dan perlindungan perempuan serta kesetaraan dan keadilan gender

c. Peningkatan peran kelembagaan dan jaringan kelembagaan pemberdayaan perempuan

\footnotetext{
8 Ibid, hlm 42
} 

d. Peningkatan upaya
perlindungan perempuan
termasuk lansia dan cacat.

2. Program Penguatan Kelembagaan Pengarusutamaan Gender

Program ini ditujukan untuk melembagakan pengarusutamaan gender di dan menjawab kebutuhan strategis gender dengan memperhatikan semua bidang pembangunan dalam rangka meningkatkan status, kedudukan, partisipasi perempuan pengalamam, kebutuhan dan masalah berbeda laki-laki dan perempuan.

3. Program Keserasian Kebijakan Peningkatan Kualitas Anak dan Perempuan

Programiniadalahuntukmeningkatkan kualitas anak dan perempuan dan mewujudkan anak yang sehat, cerdas, ceria dan berakhlak mulia serta melindungi anak dari berbagai tindak kekerasan, eksploitasi dan diskriminasi.

\section{PENUTUP}

\section{Kesimpulan}

1. Kebijakan pemerintah kabupaten Demak dalam pemberdayaan perempuan dan perlindungan anak sebagai sarana pengentasan kemiskinan adalah sebagai berikut:

a. Misi Kabupaten Demak Tahun 2011-2016 antara lain adalah meningkatkan pemberdayaan perempuan, perlindungan anak dan pengendalian pertumbuhan penduduk. Dengan program-programnya adalah:a) meningkatkan pemasyarakatan pengarusutamaan gender, b) mengembangkan kerjasama dengan organisasi-organisasi perempuan, c) membantu peran organisasi-organisasi perempuan.

b. Mengeluarkan Peraturan Bupati Nomor 07 Tahun 2012 tentang Pedoman Umum Pelaksanaan
Pengarusutamaan Gender di Kabupaten Demak. Pedoman ini bertujuan untuk: a) memberikan acuan bagi aparatur pemerintah daerah dalam menyusun strategimengintegrasikan gender yang dilakukan melalui perencanaan, pelaksanaan, penganggaran, pemantauan, dan evaluasi atas kebijakan, program, dan kegiatan pembangunan di daerah, b) mewujudkan perencanaan berperspektif gender melalui pengintegrasian pengalamam, aspirasi, kebutuhan, potensi dan penyelesaian permasalahan laki-laki dan perempuan,c) mewujudkan kesetaraan dan keadilan gender dalam kehidupan berkeluarga, berbangsa dan bernegara, d) mewujudkan pengelolaan anggaran daerah yang responsif gender,e) meningkatkan kesetaraan dan keadilan dalam kedudukan, peran dan tanggungjawab laki-laki dan perempuan sebagai insan dan sumber daya pembangunan, f) meningkatkan peran dan kemandirian lembaga yang menangani pemberdayaan perempuan.

c. Mengeluarkan SuratEdaran Kepala Daerah Nomor 401/0057/2016 tentang Perencanaan Dan Penganggaran Responsif Gender SKPD, Surat Edran tersebut antara lain berisi tentang kebijakan bagi seluruh SKPD berkewajiban untuk menyusun perencanaan dan penganggaran responsif gender pada tahun anggaran 2017. Sehubungan dengan hal tersebut seluruh SKPD agar menuyusun anggaran responsif gender.

2. Program-program Pemberdayaan Perempuan Kabupaten Demak KP2PA kabupaten Demak telah menyusun program tahun 2011-2016 yakni sebagai berikut: 
a. Visi KP2PA adalah "terwujudnya kesetaraan dan keadilan gender, kesejahteraan dan perlindungan anak dalam kehidupan keluarga, masyarakat, bangsa dan negara.

b. MisiKP2PAadalah:a)meningkatkan pengarusutamaan gender melalui fasilitas kelembagaan, kesetaraan dan keadilan gender dalam berbagai bidang kehidupan, b) meningkatkan kualitas hidup perempuan, c) mengurangi segala bentuk kekerasan berbasis gender terhadap perempuan, d) meningkatkan perlindungan anak.
2. Saran

1. Kebijakan kabupaten Demak dalam pemberdayaan perempuan hendaknya dituangkan dalam bentuk Peraturan Daerah, sehingga mendapatkan dukungan dan pengawasan rakyat melalui wakilnya di DPRD.

2. Harus ada monitoring dan evaluasi dalam pelaksanaan program kerja yang terkait dengan pemberdayaan perempuan dalam rangka pengentasan kemiskinan yang dilakukan oleh SKPD

\section{DAFTAR PUSTAKA}

\section{- Buku-buku}

Ahmad, Sukardja, 2012, Hukum Tata Negaa \& Hukum Administrasi Negara Dalam Perspektif Fikih Siyasah, Sinar Grafika, Jakarta;

Afzalur Rahman, 1995, Doktrin Ekonomi Islam, terjemahan, Economic Of Islam, oleh Soeroyo, Dana Badan Wakaf, Yogyakarta;

Bajuri Abdul Kahar dan Teguh Yuwono, 2002, Kebijakan Publik, Konsep dan Strategi, Undip, Semarang;

Euis Amalia, 2009, Keadilan Distributif Dalam Ekonomi Islam, Radjagrafindo Persada, Jakarta;

Hanif Nurcholis, 2005, Teori Dan Praktek Pemerintahan dan Otonomi Daerah, Grasindo, Jakarta;

Jimly Asshiddiqie, 2006, Pengantar Hukum Tata Negara, Jilid II, Konstitusi Press, Jakarta;

Muhammad Fauzan, 2006, Hukum Pemerintahan daerah, Kajian Hubungan Keuangan Antara Pusat Dan daerah, UII Press, Yogyakarta;

Wahbah Zuhailly, 1996, Alqur; an Paradigma Hukum Dan Paradaban, terjemahan Mohammad Luqman hakiem dan Mohammad Hariri, Risalah Gusti, Surabaya;

Moh. Mahfudz MD, 2006, Pergulatan Politik Dan Hukum Di Indonesia, Gama Media, Yogyakarta;

Muhammad Alim, 2010, Asas-asas_Negara Hukum dalam Islam, Kajian Komprehensif Islam dan Kenegaraan, LkiS, Yogyakarta;

Muhsin dan Fadillah Putra, 2002, Hukum dan Kebijakan Publik, Averroes, Malang;

Mustopadidjaja, 1992, Studi Kebijakan, Perkembangan dan Penerapan Dalam Rangka Administrasi dan Manajemen Pembangunan, LP-FEUI, Jakarta;

M. Irfan Islamy, 1986, Prinsip-prinsip Perumusan Kebijaksanaan Negara, Bina Aksara, Jakarta; Solichin Abdul Wahab, 1991, Analisis Kebijaksanaan Dan Formulasi ke Implementasi, Bumi Aksara, Jakarta; 
Saiful Bahri, et al, Hukum Dan Kebijakan publik, Yogyakarta, YPAPI, 2004.

Samodra Wibowo, 2011, Politik Perumusan Kebijakan Publik, Graha IImu, Yogyakarta;

\section{- Peraturan Perundangan}

Undang Undang Dasar Negara Republik Indonesia Tahun 1945

Undang-undang Nomor 17 Tahun 2007 tentang Rencana Pembangunan Jangka Panjang Nasional 2005-2025.

Undang-Undang Republik Indonesia Nomor 23 Tahun 2014 tentang Pemerintahan Daerah. 